Article

\title{
Characteristics of Logging Businesses across Virginia's Diverse Physiographic Regions
}

\author{
Scott M. Barrett *, M. Chad Bolding (D) and John F. Munsell \\ Department of Forest Resources and Environmental Conservation, Virginia Polytechnic Institute and \\ State University, 310 W. Campus Drive, Blacksburg, VA 24061, USA; bolding@vt.edu (M.C.B.); \\ jfmunsel@vt.edu (J.F.M.) \\ * Correspondence: sbarrett@vt.edu; Tel.: +1-540-231-6702; Fax: +1-540-231-3330
}

Received: 29 September 2017; Accepted: 21 November 2017; Published: 28 November 2017

\begin{abstract}
Logging businesses play an important role in implementing forest management plans and delivering the raw material needed by forest products mills. Understanding the characteristics of the logging workforce can help forest managers make better decisions related to harvesting operations. We surveyed logging business owners across Virginia's three physiographic regions (Mountains, Piedmont, and Coastal Plain). Overall, logging businesses reported an average production rate of $761.37 \mathrm{t} /$ business/week, but this varied substantially by region, with the highest production rates in the Coastal Plain (1403.55 t/business/week), followed by the Piedmont (824.69 t/business/week) and the Mountains (245.42 t/business/week). Many operations in the Mountains rely primarily on manual felling ( $66.6 \%$ of respondents) and these operations often have lower production rates. Across all regions, $81.7 \%$ of reported production came from operations that primarily utilized rubber-tired feller-bunchers for felling. Logging businesses were sorted based on reported production capacity and then divided into three groups (high, medium, and low production) based on total reported production. Across all regions, the majority of reported production was produced by the high production logging businesses. This was highest in the Piedmont, where the high production businesses accounted for $74.8 \%$ of total reported production.
\end{abstract}

Keywords: logging business; woody biomass; forest harvesting

\section{Introduction}

The forest industry is an important component of Virginia's economy and contributes over $\$ 17$ billion in total economic value annually [1]. More than $60 \%$ of Virginia is forested, with 16 million acres of forestland predominantly owned by private forest landowners [2]. Virginia's logging businesses primarily consist of independent contractors who work with forest landowners and others in the wood supply chain to provide the raw material needed to supply mills. Logging businesses provide critical harvesting services that help forest landowners carry out their management plans and deliver wood to Virginia's diverse wood-consuming industries.

In 2016, there were over 5000 tracts harvested in Virginia [2]. Logging businesses that harvest these tracts serve as a link between forest landowners and the mills that utilize the products coming from their land. As a result, the characteristics of logging businesses are important for forest managers and those involved in the wood supply chain. Forest management and harvesting decisions can benefit from a better understanding of the capabilities and characteristics of the local logging workforce.

Surveys of logging businesses are important for establishing information on their characteristics and can be useful for documenting and examining changes over time. Logger surveys have been used throughout the USA for determining characteristics of logging businesses. For example, Milauskas and Wang surveyed West Virginia loggers on their operational characteristics as well as their opinions 
on training needs [3]. Dirkswager et al. used a phone survey of loggers to determine practices and perspectives related to utilizing logging residues for energy in Minnesota [4]. Egan et al. surveyed New England loggers regarding their perceptions of increasing population on logging opportunities [5] and Munsell et al. studied relationship between attitudes and biomass harvesting in Virginia and North Carolina [6]. Additional logger surveys have been conducted related to specific topics such as harvesting on parcelized forestland in the Midwest [7] as well as in South Carolina [8]. Logger surveys that are repeated over time can show changes in logging practices. For example, repeated logger surveys have been conducted in Minnesota [9] and Georgia [10].

A survey was administered to Virginia logging businesses in 2009 with the intention of repeating the survey at five-year intervals [11]. The original survey established a baseline of Virginia logging business characteristics and highlighted some of the operational differences between physiographic regions in the state. This survey was performed approximately five years after the initial survey. Some additional questions were added but many relating to logging business characteristics remained the same, so comparisons can be made over time.

This is the second comprehensive survey of the characteristics of Virginia logging businesses. While some comparisons can be made to the results of the previous survey, this manuscript focuses primarily on the current survey and much of the value of repeated surveys will come in the future as multiple surveys will enable analysis of long-term trends.

\section{Methods}

A questionnaire was designed for delivery to participants in the Virginia Sustainable Harvesting and Resource Professional (SHARP) Logger Program [12]. The objective was to collect information on characteristics of Virginia logging businesses as well as to evaluate the SHARP logger program. In addition to logging business owners, the SHARP logger program includes participants who are logging business employees as well as foresters and others that choose to participate in the program. Therefore, the questionnaire included two sections. The first section was a program evaluation section that included 12 questions related to the participants' demographics and to program evaluation and training needs. All respondents were able to categorize their primary occupation in the program evaluation section, while logging business owners completed a second section in order to provide additional characteristics of their harvesting operations. In the case of logging businesses with multiple owners, participants were asked to choose one owner to complete the business owner section and complete one questionnaire per business. In Virginia, logger training is not required by law, so the exact number of logging businesses is not known. However, loggers are required to notify the Virginia Department of Forestry (VDOF) of timber harvests so harvested tracts can be inspected for compliance with the silvicultural water quality law. Based on a study of reported data from VDOF harvest notifications during 2015-2016, there were approximately 1000 individuals who notified the VDOF of at least one timber harvest [13]. We would therefore assume there are a maximum of 1000 active logging businesses.

The logging business owner section included a total of 36 questions related to their harvesting operations such as harvesting equipment, the size and characteristics of their operation, as well as the markets and business environment they work in and tracts they harvest. The questionnaire included a combination of multiple choice, fill-in-the-blank, and open-ended questions. The questionnaire was mailed to current participants in the Virginia SHARP Logger Program. The survey was conducted based on the Dilman method [14] using a series of mailings including a pre-notice letter, followed by the questionnaire, then a reminder letter, and a second questionnaire mailed to those who had not returned the initial questionnaire. A total of 1607 questionnaires were mailed in the third and fourth quarters of 2014. Seven were returned as undeliverable or invalid, resulting in a total of 1600 questionnaires mailed to participants in the SHARP Logger Program.

Written responses from questionnaires were coded and entered into a spreadsheet then analyzed using JMP Pro version 13 [15]. Means testing utilized analysis of variance and the Tukey-Kramer HSD 
(honest significant difference) test. Categorical responses were compared using the Chi Square test. Respondents were grouped into physiographic regions (Figure 1) based on the county the respondent indicated as their center of operations. Counties were grouped into physiographic regions based on regions used by the U.S. Forest Service [16], with the northern and southern Piedmont grouped into a single Piedmont region and northern and southern mountains grouped into a single mountain region. These are the same regional boundaries used in the 2009 survey of Virginia loggers [11]. Respondents were asked to report production levels in the units they commonly use, which was either tons or truck loads produced per week. Results from the previous survey [11] were reported as truck loads produced, which is the most common metric reported by loggers. However, because of differences in average payloads depending on trucking configurations, results for this survey were converted to a common unit on the basis of tonnes (metric tons, $t$ ) produced. Production levels reported in truckloads were converted to tonnes based on the reported trucking configuration the business most commonly uses. Average payloads for different trucking configurations were determined based on discussion with local industry professionals. A payload conversion factor of $22.7 \mathrm{t}$ ( 25 tons) per load was used for tractor-trailers, as well as tandem or tri-axle trucks with a pup trailer. A payload conversion factor of $8.2 \mathrm{t}$ (9 tons) per load was used for single-axle trucks, $12.7 \mathrm{t}$ (14 tons) for tandem-axle trucks, and $17.2 \mathrm{t}$ (19 tons) for tri-axle trucks. Based on standard practices for this region, all weights reported by logging businesses were assumed to be in green tonnes and typical truck payloads were based on green tonnes.

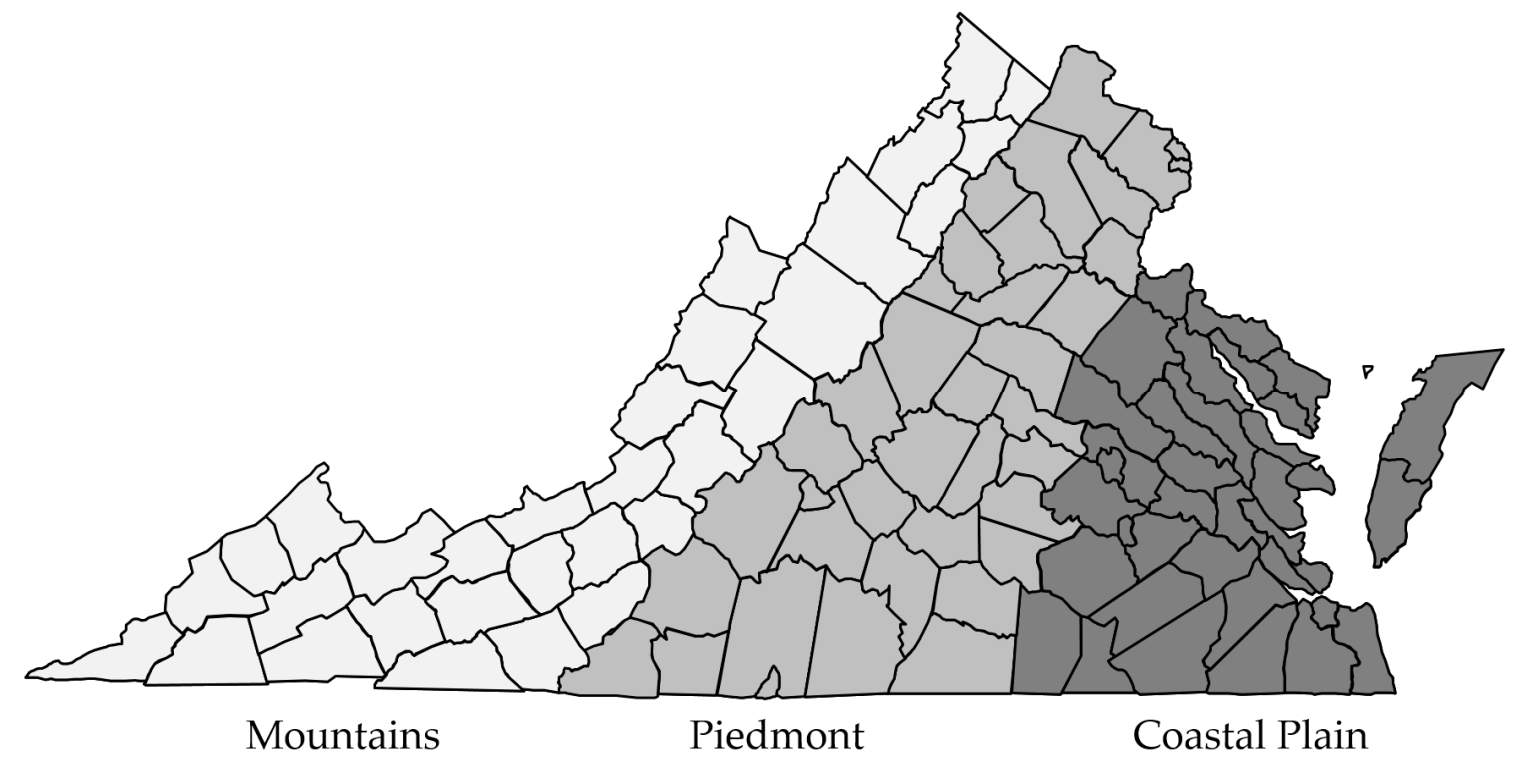

Figure 1. Virginia county boundaries used to group logging businesses by physiographic region (map not to scale).

\section{Results and Discussion}

\subsection{Response Rate and Owner Demographics}

A total of 847 questionnaires were completed and returned for a 53\% response rate. Of the 847 responses, 400 (47.2\%) indicated they were logging business owners. Data reported here are from the 400 logging business owner responses. Based on VDOF harvest notification data [13], if we assume there are a maximum of approximately 1000 active logging businesses, then survey responses would represent about $40 \%$ of all logging businesses in Virginia. Logging businesses included both full-time $(87 \%)$ as well as part-time $(13 \%)$ logging operations. Virginia logging business owners were predominantly men $(99.5 \%)$, with an average age of 51.2 years (standard deviation $(\mathrm{SD})=12.3$ ). Respondents indicated they had been operating their own logging business for an average of 22.6 years $(\mathrm{SD}=13.9)$. The majority $(91.2 \%)$ indicated they were White/Caucasian, with $8.3 \%$ Black/African 
American and $0.5 \%$ other. Owner demographics are similar to those from the 2009 survey [11]; however, the average age shows an increase from 48.6 years in 2009 to 51.2 in 2014.

Respondents represented logging businesses operating across all three physiographic regions of Virginia including the Mountains (105), Piedmont (192), and Coastal Plain (70), as well as adjoining states (24); in some cases they did not specify a region (9). These three physiographic regions of Virginia would be similar to physiographic regions occurring throughout much of the Southeastern USA. Owners were asked to indicate their level of formal education. Across all regions, high school graduates were the most common (Table 1). Business owners in the Coastal Plain tended to have the highest level of formal education, with $26.1 \%$ indicating they were college graduates.

Table 1. Logging business owner education level by physiographic region.

\begin{tabular}{ccccc}
\hline & \multicolumn{3}{c}{ Percent of Responses for Level of Formal Education } \\
\hline & Some High School & High School Graduate & Some College & College Graduate \\
\hline Mountains & 29.5 & 55.3 & 7.6 & 7.6 \\
Piedmont & 24.2 & 54.2 & 13.7 & 7.9 \\
Coastal Plain & 13.0 & 47.9 & 13.0 & 26.1 \\
Overall & 24.3 & 53.5 & 11.1 & 11.1 \\
\hline
\end{tabular}

\subsection{Harvest Types and Tract Characteristics}

Respondents were asked to report the type of harvests they performed over the past year (Figure 2). Similar to the 2009 survey of Virginia loggers [11], the highest percentage of harvests reported in the Mountains were hardwood selection cuts. However this survey showed that the most common harvest type in the Coastal Plain was a pine clearcut, whereas in 2009 it was a pine thinning [11].

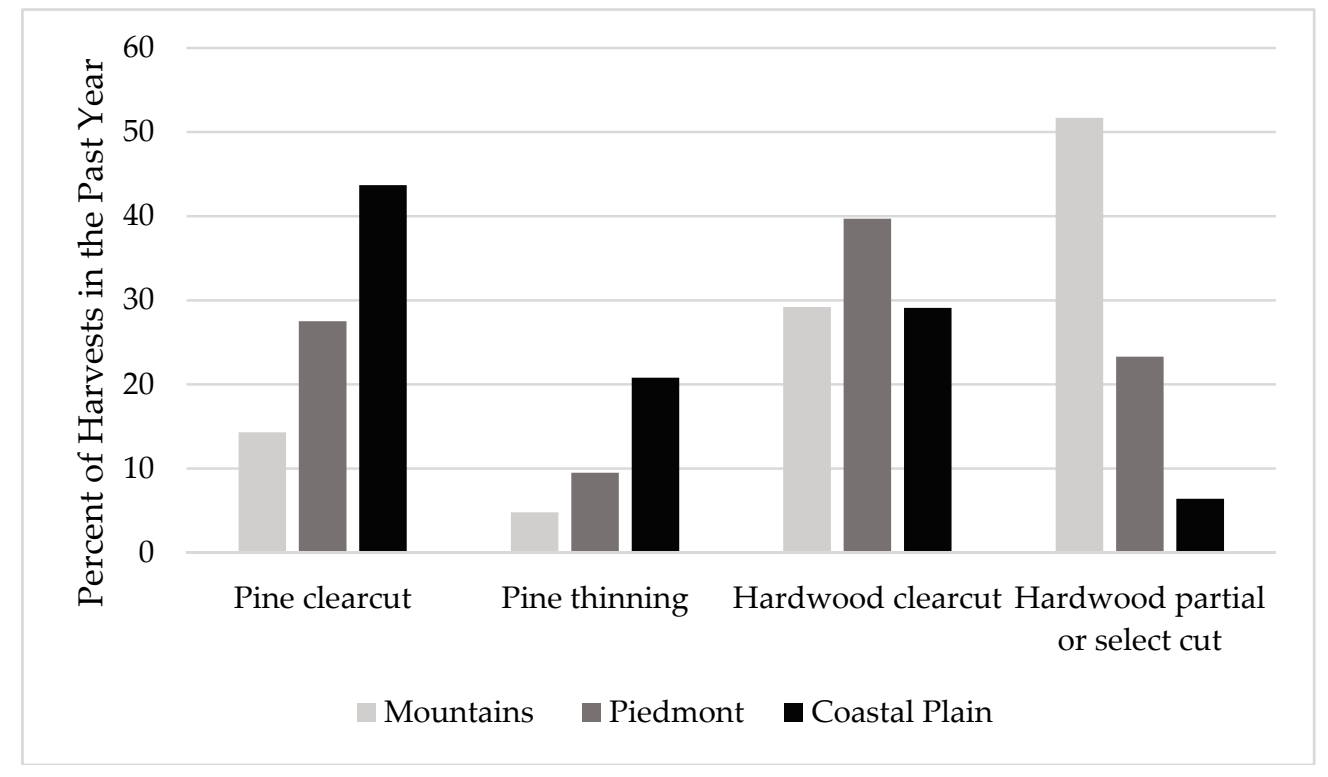

Figure 2. Reported type of harvests performed in the past year by physiographic region.

As expected, based on the most prevalent types of harvests reported (Figure 2), the primary product harvested in the Mountains was hardwood sawtimber while in the Coastal Plain, the most commonly reported product harvested was pine pulpwood (Figure 3). The most commonly reported average hauling distance for their primary product was between 20 and 60 miles and the most commonly reported distance moved between tracts was 20-40 miles. 


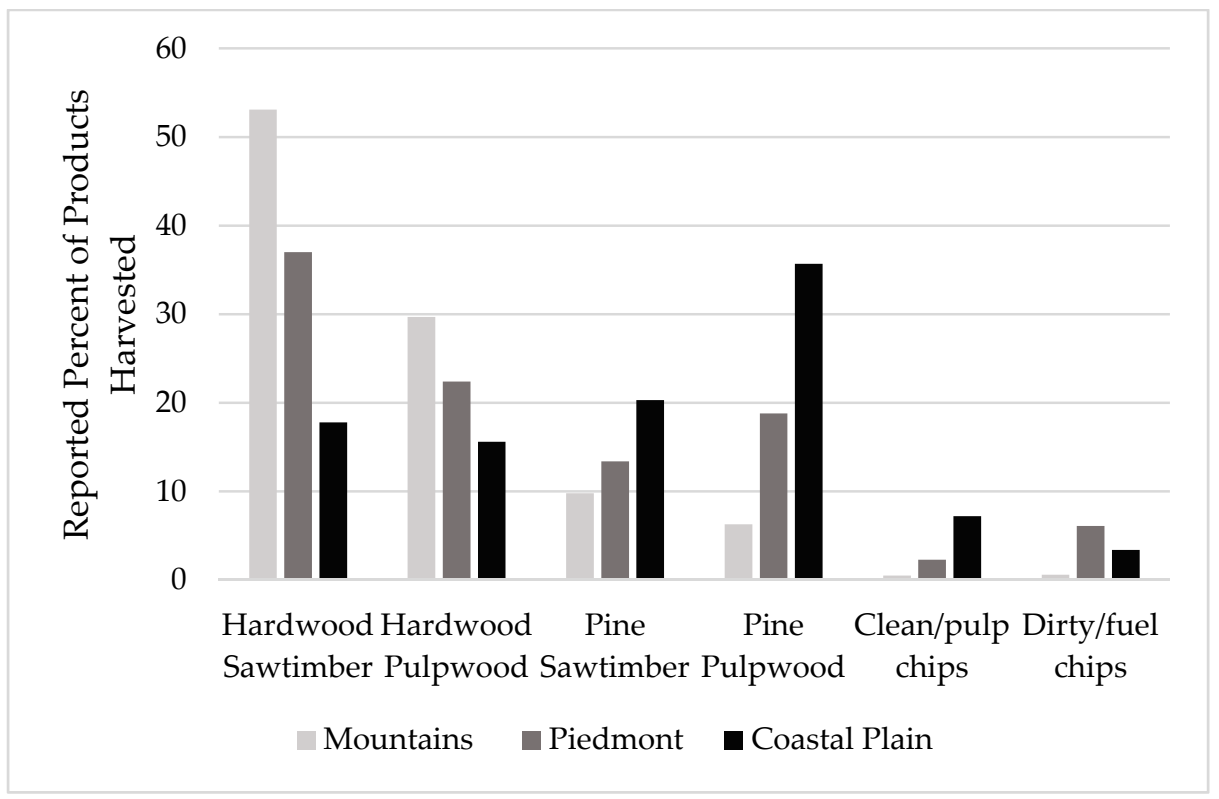

Figure 3. Reported percentage of products harvested in the past year by physiographic region.

Across all regions, the most commonly reported average harvest size over the past year was $40-80$ acres. These harvests occur predominantly on forestland owned by private individuals. Harvests on forest industry owned land represented a relatively small portion of all harvests, with $5.2 \%$ or less of harvests in any region (Table 2).

Table 2. Type of land ownership where business owners harvested timber in the past year.

\begin{tabular}{ccccc}
\hline & \multicolumn{4}{c}{ Mean Response Percentage } \\
\hline & Mountains & Piedmont & Coastal Plain & Overall \\
\hline Private individuals & 92.0 & 91.3 & 83.2 & 89.6 \\
Forest industry & 2.9 & 5.2 & 4.9 & 4.9 \\
US Forest Service & 4.4 & 0 & 0 & 1.3 \\
State Forests & 0 & 0.1 & 0.3 & 0.1 \\
TIMO/REIT & 0 & 3.3 & 9.6 & 3.3 \\
Other & 0.7 & 0.1 & 2.0 & 0.8 \\
\hline
\end{tabular}

TIMO = Timberland Investment Management Organization, REIT = Real Estate Investment Trust.

The way loggers acquired the timber they harvested varied by region as well. Business owners were asked to indicate the percent of their harvests in the past year that derived from timber where they bought or negotiated the sale directly, and the percent that was contract logging of timber bought by someone else. The majority of harvests across all regions were bought or negotiated directly by the logger. The coastal plain had the highest reported percentage of sales where the logger was contract logging timber that was bought by someone else (Figure 4).

For those sales where the logger indicated that they bought the timber, they were asked specifically how the timber was purchased. Options for the type of sale included lump sum, cut on "shares", which was defined as the "landowner receives a set percentage of delivered price received as the tract is harvested", or per unit/pay as cut. Per unit sales were defined as "landowner receives a set price per ton/MBF (thousand board feet) for each ton/MBF as tract is harvested". In the Mountains, the majority of sales were cut on "shares", whereas in the Coastal Plain the majority of sales were per unit/pay as cut (Figure 5). 


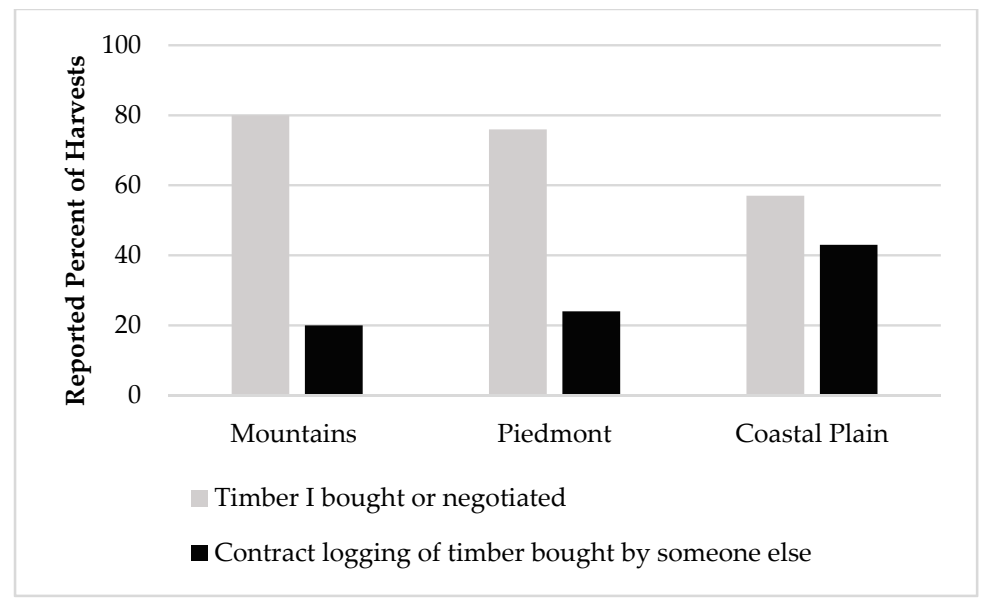

Figure 4. Reported source of timber harvested in past year.

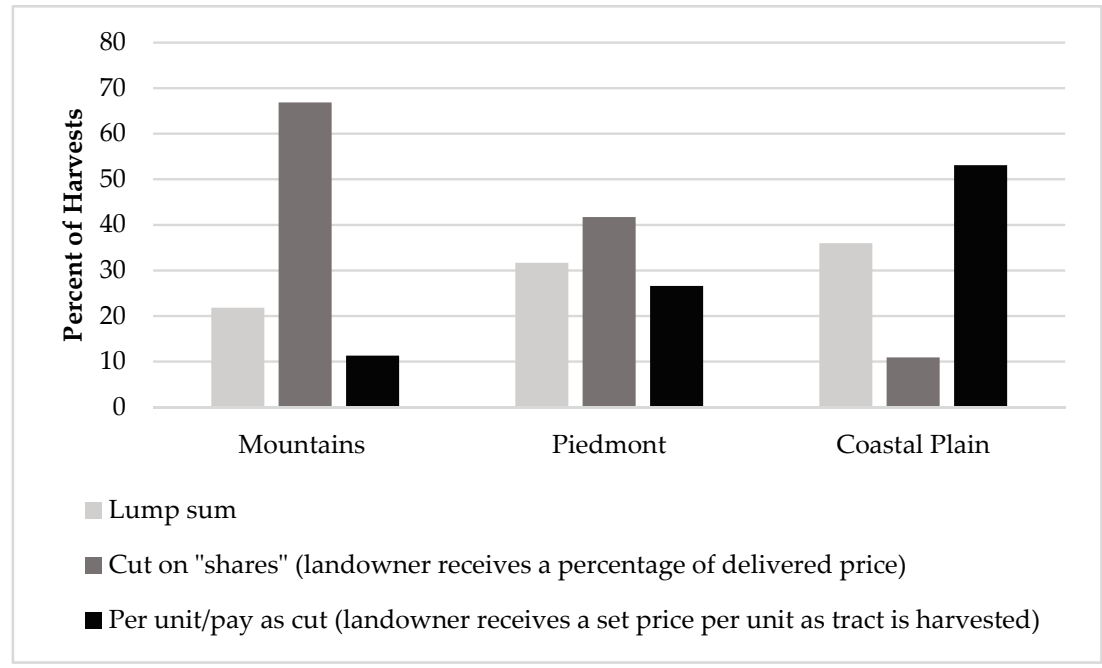

Figure 5. Reported sale type for timber bought by loggers.

\subsection{Harvesting System and Production Characteristics}

The majority of harvests reported were on forestland owned by private individuals (Table 2). Forest landowners often rely on harvests to meet their forest management objectives. Without a viable logging workforce capable of implementing multiple types of harvests, many landowners would not be able to meet their forest management objectives. The production level and type of equipment utilized on a logging operation are two important factors for determining the capabilities of a logging operation. Awareness of the characteristics and types of logging businesses within a region and the equipment they utilize can help forest managers select the most appropriate operation to meet their forest harvesting and management objectives.

Logging business owners were asked to report production in terms of loads or tons produced per crew per week, and number of crews owned. Values reported in loads per week were converted to tonnes per week based on average payloads for the trucking configuration they most commonly used. Tonnes per business per week was based on production per crew and the number of crews owned per business. Total reported production in the three regions was 240,727 tonnes per week with the majority of the total production reported in the Piedmont region (57.9\%) and only $8.9 \%$ from the Mountains (Table 3). There were considerable differences in average production rates by region. Production in terms of $t / c r e w /$ week and $t /$ business/week both showed significant differences between regions $(P<0.0001)$. The Coastal Plain had the highest average tonnes per business per week (1403.55), tonnes per crew per 
week (864.01), and also had more crews per business (1.48). Compared to reported production values from the 2009 survey [11], the overall average number of crews per business increased from 1.16 to 1.20. The number of crews per business stayed the same in the Mountains, but increased in the Piedmont (from 1.12 to 1.2) and Coastal Plain (from 1.43 to 1.48). The number of workers per crew was nearly identical to 2009 levels in the Mountains and Piedmont and decreased from an average of 4.21 to 4.16 in the Coastal Plain. Production levels in 2009 were reported in loads per week with a statewide average of 20.42 loads per crew per week. If we assumed this production was entirely from tractor-trailers (highest average payloads) with a payload of $22.7 \mathrm{t} /$ load ( 25 tons) then that would be $463.1 \mathrm{t} / \mathrm{crew} /$ week. Assuming tractor-trailer payloads for all production would result in the highest possible production levels from the 2009 survey results, which is still lower than the 2014 calculated overall average production level of $530.9 \mathrm{t} / \mathrm{crew}$ / week. Increases in production per crew since the 2009 survey could be from increased mechanization and overall efficiency, but are also likely a result of improved markets and increased demand following the recession, which likely impacted operations during the previous survey timeframe.

Business owners were asked to estimate the total current value for all logging equipment used for producing wood (excluding trucks and trailers). We used a method similar to Baker and Greene's [10] to evaluate production in terms of annual tonnes per \$1000 investment and found an overall average of approximately 112.6 tonnes per $\$ 1000$ investment. This was highest in the Coastal Plain at over 125 tonnes annually per $\$ 1000$ investment (Table 3). Baker and Greene [10] looked only at feller-buncher/grapple skidder crews in Georgia between 1987 and 2007 and reported values for tonnes per $\$ 1000$ investment that ranged between 112 and 165 . They calculated a value for logging equipment based on reported equipment type and age, whereas we asked respondents to estimate the value of their equipment. However, the results are similar to their findings, especially in the Coastal Plain, which predominantly uses feller-buncher/grapple skidder operations.

Table 3. Logging business production characteristics by region.

\begin{tabular}{|c|c|c|c|c|c|}
\hline & $\mathbf{n}$ & Mean & MIN & MAX & SD \\
\hline \multicolumn{6}{|l|}{ Mountains } \\
\hline Crews per business & 99 & 1.05 & 1 & 2 & 0.22 \\
\hline Workers per crew & 98 & 2.80 & 1 & 12 & 1.50 \\
\hline Tonnes per crew per week & 89 & 224.62 & 16 & 1247 & 201.35 \\
\hline Tonnes per business per week & 87 & 245.42 & 16 & 1247 & 251.27 \\
\hline Total current investment ${ }^{1}$ (thousand USD) & 87 & 257.68 & 2 & 3000 & 514.39 \\
\hline Annual tonnes per $\$ 1000$ investment $^{2}$ & 73 & 99.18 & 10 & 499 & 92.02 \\
\hline \multicolumn{6}{|l|}{ Piedmont } \\
\hline Crews per business & 180 & 1.20 & 1 & 4 & 0.51 \\
\hline Workers per crew & 178 & 3.31 & 1 & 15 & 1.85 \\
\hline Tonnes per crew per week & 169 & 581.84 & 11 & 2948 & 509.77 \\
\hline Tonnes per business per week & 169 & 824.69 & 11 & 6804 & 1125.81 \\
\hline Total current investment ${ }^{1}$ (thousand USD) & 158 & 491.81 & 5 & 6000 & 712.42 \\
\hline Annual tonnes per $\$ 1000$ investment $^{2}$ & 149 & 113.01 & 4 & 653 & 97.50 \\
\hline \multicolumn{6}{|l|}{ Coastal Plain } \\
\hline Crews per business & 64 & 1.48 & 1 & 5 & 0.91 \\
\hline Workers per crew & 64 & 4.16 & 1 & 11 & 1.85 \\
\hline Tonnes per crew per week & 57 & 864.01 & 23 & 2268 & 509.45 \\
\hline Tonnes per business per week & 57 & 1403.55 & 23 & 6350 & 1396.08 \\
\hline Total current investment ${ }^{1}$ (thousand USD) & 56 & 794.73 & 10 & 5000 & 919.48 \\
\hline Annual tonnes per $\$ 1000$ investment $^{2}$ & 49 & 125.17 & 9 & 680 & 115.51 \\
\hline \multicolumn{6}{|l|}{ Overall $^{3}$} \\
\hline Crews per business & 373 & 1.20 & 1 & 5 & 0.55 \\
\hline Workers per crew & 369 & 3.29 & 1 & 15 & 1.77 \\
\hline Tonnes per crew per week & 339 & 530.94 & 11 & 3062 & 505.56 \\
\hline Tonnes per business per week & 336 & 761.37 & 11 & 6804 & 1105.24 \\
\hline Total current investment ${ }^{1}$ (thousand USD) & 328 & 462.07 & 2 & 6000 & 704.14 \\
\hline Annual tonnes per $\$ 1000$ investment $^{2}$ & 291 & 112.56 & 4 & 680 & 99.48 \\
\hline
\end{tabular}

${ }^{1}$ Indicates current value of harvesting equipment excluding trucking. ${ }^{2}$ Annual production (tonnes) calculated using reported weekly production $\times 50$ weeks $/$ year. ${ }^{3}$ Includes responses from all Virginia regions and adjoining states or regions not specifically identified. 
Reported production levels (Table 3) indicate that there is considerable variation in weekly production between businesses. To further compare production levels, the businesses were sorted by region based on the total reported tonnes of production per business. Businesses were then categorized into groups based on reported production levels. The categories were high (upper $1 / 3$ of businesses), medium, and low (lower $1 / 3$ of businesses) (Figure 6). Results indicate that production is not evenly distributed across logging businesses, and a relatively small proportion of the businesses account for the majority of production. Across all regions, the high-production businesses accounted for over two-thirds of all production and the low-production businesses accounted for less than $10 \%$ of all reported production. This was most pronounced in the Piedmont, where the high-production group accounted for nearly $75 \%$ of production.

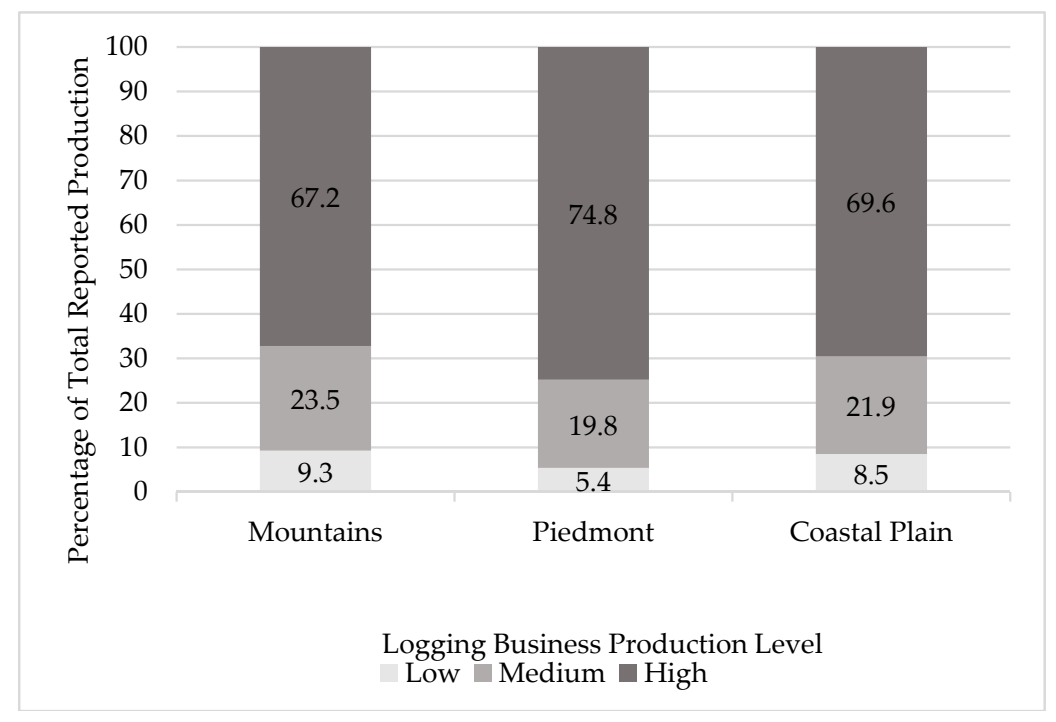

Figure 6. Percentage of total reported production by region associated with low, medium, and high production logging businesses when categorized based on the upper, middle, and lower thirds of logging business production levels.

Business owners were asked to indicate the equipment utilized for different harvesting functions on their operations. They were provided a list of common equipment options for each harvesting function and were asked to circle the one that they most commonly used. They were also provided an option for listing "other" equipment used for that function. While almost all types of equipment can be found on operations in each region, the most common types of equipment utilized varied by region (Table 4). Chainsaws were the most common felling method reported by businesses in the Mountains (88.4\%), while rubber-tired feller-bunchers were most common in the Coastal Plain $(84.1 \%)$. The Mountains showed the most diversity in terms of trucking configurations, while operations in the Piedmont and Coastal Plain predominantly utilized tractortrailers.

The percent of all responses by logging businesses shows how there is diversity in terms of the types of equipment utilized on harvesting operations (Table 4). However, there are also substantial differences in the overall production rates between different types of operations (Figure 6). Therefore, we also determined the percent of overall total reported production that was produced by businesses commonly utilizing that type of equipment for a specific harvesting function. This shows the relative proportion of all timber harvested using that method. Some harvesting methods tend to be less productive in terms of tonnes produced. For example, overall, $43.7 \%$ of respondents indicated that they primarily used a chainsaw for felling; however, only $10.1 \%$ of all reported production was from operations primarily felling with chainsaws (Table 4). While there are multiple equipment types used in each region, the overall majority of production is felled with rubber-tired feller-bunchers $(81.7 \%)$, skidded with grapple skidders (93.2\%), delimbed using pull-through delimbers $(64.6 \%)$, bucked with a buck/slasher saw $(88.9 \%)$, loaded with a trailer mounted knuckleboom loader $(90.0 \%)$, and trucked using a tractor-trailer $(90.9 \%)$. 
Table 4. Equipment used for each harvesting function. Percent of reported production represents the proportion of overall total reported production (tonnes) associated with businesses indicating they most commonly utilized that equipment.

\begin{tabular}{|c|c|c|c|c|c|c|c|c|}
\hline \multicolumn{9}{|c|}{ \% Responses (\% of Overall Total Reported Production in Tonnes) } \\
\hline & \multicolumn{2}{|c|}{ Mountains } & \multicolumn{2}{|c|}{ Piedmont } & \multicolumn{2}{|c|}{ Coastal Plain } & \multicolumn{2}{|c|}{ Overall } \\
\hline \multicolumn{9}{|l|}{ Felling } \\
\hline Chainsaw & 88.4 & $(66.6)$ & 29.6 & $(6.7)$ & 11.1 & $(0.6)$ & 43.7 & $(10.1)$ \\
\hline Rubber-tired feller-buncher & 4.9 & $(13.8)$ & 60.7 & $(85.6)$ & 84.1 & (93.7) & 48.2 & (81.7) \\
\hline Tracked feller-buncher & 3.9 & $(15.4)$ & 1.1 & $(0.8)$ & 1.6 & $(1.3)$ & 1.8 & $(2.1)$ \\
\hline Cut-to-length harvester & 0 & $(0)$ & 0.5 & $(0.3)$ & 0 & (0) & 0.3 & $(0.2)$ \\
\hline Other/Multiple ${ }^{1}$ & 2.9 & $(4.1)$ & 8.1 & $(6.6)$ & 3.2 & $(4.4)$ & 6.0 & $(5.9)$ \\
\hline \multicolumn{9}{|l|}{ Skidding } \\
\hline Cable skidder & 48.0 & $(35.4)$ & 11.4 & $(1.7)$ & 6.3 & $(0.4)$ & 22.1 & $(4.4)$ \\
\hline Grapple skidder & 38.2 & $(56.1)$ & 78.8 & $(96.0)$ & 92.1 & (99.6) & 68.2 & (93.2) \\
\hline Forwarder & 1.0 & $(0.5)$ & 0.5 & (0) & 0 & (0) & 0.5 & $(<0.1)$ \\
\hline Bulldozer & 2.0 & $(0.3)$ & 2.2 & $(<0.1)$ & 0 & (0) & 1.6 & $(<0.1)$ \\
\hline Other/Multiple ${ }^{1}$ & 10.8 & $(7.7)$ & 7.1 & $(2.3)$ & 1.6 & $(<0.1)$ & 7.6 & $(2.4)$ \\
\hline \multicolumn{9}{|l|}{ Delimbing } \\
\hline Chainsaw & 84.4 & $(61.9)$ & 36.9 & $(12.5)$ & 14.1 & $(0.9)$ & 46.6 & $(13.0)$ \\
\hline Delimbing gate & 1.0 & $(2.1)$ & 5.6 & $(5.5)$ & 7.8 & $(13.1)$ & 4.5 & (7.5) \\
\hline Pull-through delimber & 8.7 & $(18.0)$ & 46.9 & $(63.1)$ & 70.3 & $(76.3)$ & 40.2 & (64.6) \\
\hline Chain-flail delimber & 0 & $(0)$ & 1.1 & $(0.9)$ & 4.7 & $(5.4)$ & 1.3 & $(2.2)$ \\
\hline Stroke delimber & 1.0 & $(4.2)$ & 2.8 & $(10.1)$ & 0 & (0) & 1.6 & (5.6) \\
\hline Other/Multiple ${ }^{1}$ & 4.9 & $(13.8)$ & 6.7 & $(7.9)$ & 3.1 & $(4.3)$ & 5.8 & (7.1) \\
\hline \multicolumn{9}{|l|}{ Bucking } \\
\hline Chainsaw & 40.2 & $(21.0)$ & 18.1 & (3.2) & 13.6 & $(5.2)$ & 23.7 & $(5.5)$ \\
\hline Buck/Slasher saw & 52.6 & $(76.0)$ & 79.1 & $(89.6)$ & 77.9 & $(90.0)$ & 71.3 & $(88.9)$ \\
\hline Swing-boom processor & 0 & $(0)$ & 0 & (0) & 1.7 & $(<0.1)$ & 0.3 & $(<0.1)$ \\
\hline Tree length only (no bucking) & 0 & (0) & 1.7 & $(4.1)$ & 3.4 & $(2.5)$ & 1.4 & $(3.0)$ \\
\hline Other/Multiple ${ }^{1}$ & 7.2 & (3.0) & 1.1 & $(3.1)$ & 3.4 & $(2.3)$ & 3.3 & (2.6) \\
\hline \multicolumn{9}{|l|}{ Loading } \\
\hline Trailer mounted knuckleboom & 50.5 & $(56.6)$ & 78.4 & $(90.3)$ & 88.7 & $(97.1)$ & 73.0 & $(90.0)$ \\
\hline Mobile knuckleboom & 30.1 & (22.4) & 10.8 & $(8.2)$ & 3.2 & $(0.4)$ & 14.4 & $(6.5)$ \\
\hline Self-loading trucks & 6.8 & $(4.9)$ & 0.5 & $(0.4)$ & 0 & $(0)$ & 2.1 & (0.6) \\
\hline Front-end loader & 5.8 & (1.4) & 4.9 & $(0.3)$ & 3.2 & $(0.2)$ & 4.7 & $(0.4)$ \\
\hline Other/Multiple ${ }^{1}$ & 6.8 & $(14.7)$ & 5.4 & $(0.8)$ & 4.9 & $(2.3)$ & 5.8 & (2.5) \\
\hline \multicolumn{9}{|l|}{ Trucking } \\
\hline Tractor-trailer & 23.0 & $(35.5)$ & 70.6 & $(95.1)$ & 89.5 & $(99.2)$ & 58.5 & $(90.9)$ \\
\hline Single axle & 7.0 & $(1.8)$ & 8.3 & $(0.7)$ & 3.5 & $(0.1)$ & 7.4 & $(0.7)$ \\
\hline Tandem axle & 16.0 & (5.7) & 9.4 & (1.3) & 1.8 & $(0.7)$ & 10.9 & (1.7) \\
\hline Tandem with pup trailer & 8.0 & (11.3) & 2.8 & $(1.1)$ & 0 & $(0)$ & 4.4 & (1.9) \\
\hline Tri-axle & 14 & $(8.8)$ & 5.0 & (1.6) & 0 & (0) & 6.3 & (1.6) \\
\hline Tri-axle with pup trailer & 15 & $(20.6)$ & 1.1 & $(.2)$ & 0 & (0) & 4.6 & (1.8) \\
\hline Other/Multiple ${ }^{1}$ & 17.0 & $(16.3)$ & 2.8 & (0) & 5.2 & $(<0.1)$ & 7.9 & $(1.4)$ \\
\hline \multicolumn{9}{|l|}{ Chipping (or biomass production) } \\
\hline Whole tree (dirty chips) & 7.6 & $(24.1)$ & 29.2 & $(51.5)$ & 18.6 & $(29.7)$ & 20 & $(39.8)$ \\
\hline Whole tree $\mathrm{w} /$ flail (clean chips) & 1.0 & (3.2) & 2.6 & $(1.4)$ & 1.4 & $(4.3)$ & 1.7 & $(2.3)$ \\
\hline Whole tree $\mathrm{w} /$ flail + grinder & 0 & (0) & 0.5 & $(1.6)$ & 2.9 & $(10.2)$ & 0.8 & $(4.1)$ \\
\hline Other/Multiple ${ }^{1}$ & 1.0 & (0) & 1.6 & $(3.9)$ & 4.3 & $(5.7)$ & 2.0 & $(4.2)$ \\
\hline No chipper reported & 90.4 & $(72.7)$ & 66.1 & $(41.6)$ & 72.8 & $(50.1)$ & 75.5 & $(49.6)$ \\
\hline
\end{tabular}

${ }^{1}$ Respondents were asked to select the most common one, but sometimes selected multiple options.

\subsection{Biomass Harvesting}

Respondents were asked to report if they harvested biomass or "fuel chips" for energy. Overall, $25 \%$ of businesses reported they harvested biomass. Previous studies have noted that biomass harvests in Virginia were typically performed on integrated harvesting operations, where biomass is produced from residues concurrently with roundwood production [17]. With integrated harvesting operations, biomass harvesting is often more feasible for businesses with higher production levels because there is a larger quantity of residues available and it is more likely that the operation could justify adding a 
chipper to utilize residues for energy. Biomass harvesting was compared by region across production categories (high, medium, and low production). Production of biomass was more common among the higher production levels, with the majority of the high-production businesses producing biomass in the Piedmont and Coastal Plain (Table 5). Significant differences across business production categories were observed in the Mountains $\left(X^{2}=0.0054\right)$, Piedmont $\left(X^{2}<0.0001\right)$, and Coastal Plain $\left(X^{2}=0.0421\right)$. This question related to harvesting fuel chips was independent of the question related to type of equipment used for chipping (Table 4), so while the percentages are similar to those reporting chippers they do not match exactly because respondents who indicated they produced fuel chips may not have all reported the primary type of equipment utilized.

Table 5. Percent of businesses indicating harvest of biomass/fuel chips by region across production category when sorted by production level.

\begin{tabular}{cccc}
\hline & \multicolumn{3}{c}{ Percent Harvesting Biomass } \\
\hline Production Category & Mountains & Piedmont & Coastal Plain \\
\hline All respondents & 8.7 & 35.2 & 29.2 \\
High Production (Upper third) & 20.7 & 60.7 & 52.6 \\
Medium Production (Middle third) & 3.4 & 39.3 & 26.3 \\
Low Production (Lower third) & 0 & 11.1 & 15.8 \\
\hline
\end{tabular}

\subsection{Harvest Planning and Implementation of BMPS}

Harvest planning is an important tool to ensure efficient and effective logging operations. Pre-harvest planning of items such as roads, skid trails, landings, and stream crossings can impact the productivity of the operation, and can also have an impact in terms of compliance with implementation of Best Management Practices (BMPs) for water quality. Implementation of BMPs for water quality is important throughout the USA [18] and responses indicate that Virginia logging businesses invest a substantial amount of time in pre-harvest planning and the implementation of BMPs to protect water quality.

Loggers in the Mountains and Piedmont tended to spend more time on pre-harvest planning than those in the Coastal Plain. The most common response indicated that they typically spend a half to a full day per tract on pre-harvest planning, while those in the Coastal Plain tended to spend a half day or less (Figure 7). This is likely due to the more challenging terrain in the Mountains and Piedmont. Similarly, logging businesses in the Mountains tended to spend more time per tract closing out the site and implementing BMPs. The most common response in the Mountains was 1-2 days spent closing out the tract, whereas the most common time reported in the Piedmont and Coastal Plain was a half to a full day (Figure 8).

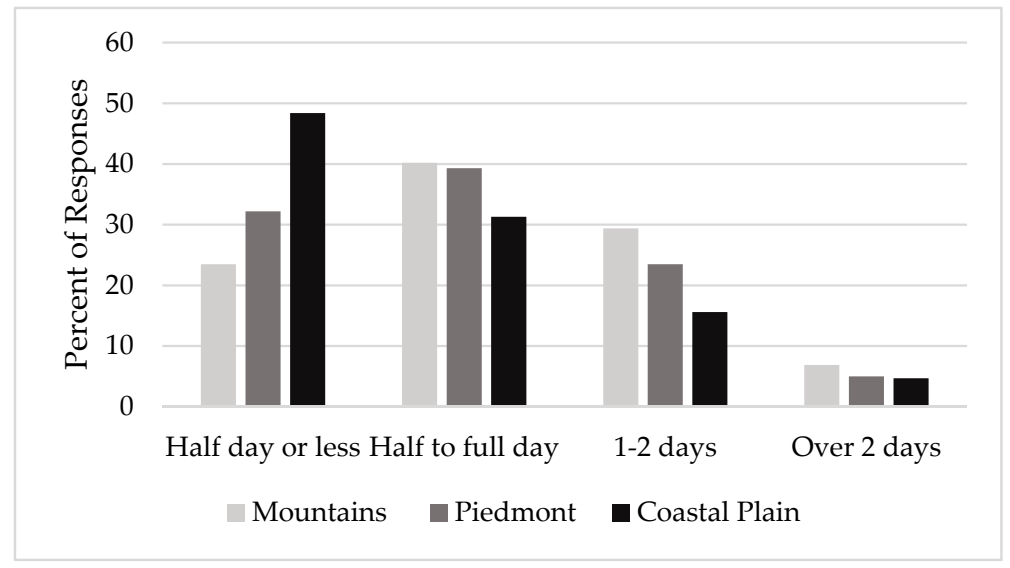

Figure 7. Typical time spent per tract on pre-harvest planning to locate roads, skid trails, landings, and stream crossings. 


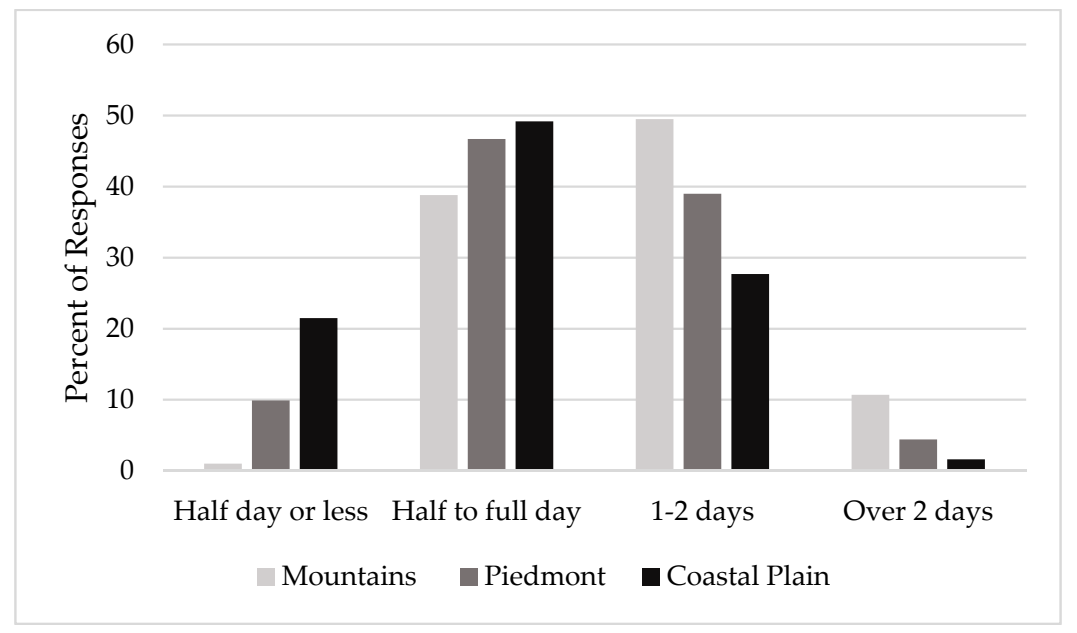

Figure 8. Typical time spent per tract on closing out the site and implementing Best Management Practices (BMPs) for water quality.

\subsection{Use of Technology and Common Operational Challenges}

Owners were asked about the use of various types of technology in their business (Table 6). Similar to other operational characteristics, this also varied by region. Use of all technologies across all regions showed increases from the 2009 survey. It is interesting to note that the reported percentage of e-mail use is higher than use of the Internet for businesses in the Piedmont and Coastal Plain. This could potentially be because the owners were not necessarily thinking of e-mail as using the Internet and thought of Internet usage as more related to things such as company websites, social media, online purchasing, or other web-based activities.

Table 6. Percentage by physiographic region of logging business owners indicating use of different technologies in their business.

\begin{tabular}{cccc}
\hline & \multicolumn{3}{c}{ Percent Who Indicated Use of This Technology } \\
\hline Technology & Mountains & Piedmont & Coastal Plain \\
\hline GPS & 18.8 & 29.8 & 44.6 \\
Computer mapping & 13.7 & 27.0 & 27.7 \\
Internet & 43.1 & 51.1 & 75.4 \\
E-mail & 39.6 & 53.9 & 80.0 \\
\hline
\end{tabular}

${ }^{1}$ Respondents were asked to report all technologies they used, so percentages may be greater than $100 \%$.

At the end of the questionnaire, respondents were given an open-ended question related to the biggest problem they faced in their business. There was considerable variation in these responses and many were hard to categorize; however, there were some common responses. Common issues cited by business owners often related to challenges with labor and dealing with employees, e.g., "getting reliable help", or "lack of qualified personnel at a reasonable rate", or "finding people who are willing to show up for work". Other common problems identified included complying with regulations, especially regulations related to transportation and trucking. With most logging businesses, fuel for trucks and in-woods equipment can be a major expense, so it is not surprising that one of the common problems identified was the cost of fuel. Other common expenses in logging operations were identified as a problem, such as the cost of insurance, parts, and new equipment. Prices received for their products at the mill were also a common problem identified by business owners. While some problems such as finding qualified employees or dealing with regulations may be common in any business, some problems identified by logging businesses are somewhat unique to the industry. For example, 
some owners reported challenges related to procuring the future tracts they will harvest, e.g., "running out of timber to harvest", "lack of timber", or "trying to find timber close to home". Weather in general was listed as a problem, as well as finding "winter tracts" or tracts with suitable ground conditions that could be harvested during the typically wetter winter months.

\section{Conclusions}

Logging businesses vary substantially by physiographic region in Virginia. Overall, the majority of harvests occurred on forest lands owned by private individuals (89.6\%), and private landowners often have multiple objectives for their forest lands. A diverse logging workforce in terms of size, equipment, and type of products typically harvested may better enable logging businesses to effectively work with a diverse group of private landowners who often have multiple forest management objectives.

Logging business production rates were one of the major differences by region. Average production rates for businesses in the Coastal Plain were more than five times those in the Mountains. This could be the result of a number of operational differences, including smaller crews, fewer crews per business, and a greater reliance on manual felling in the Mountains. While a wide variety of logging operations can be found in any region, the vast majority of reported production across Virginia was felled with a rubber-tired feller-buncher (81.7\%), skidded with a grapple skidder (93.2\%), loaded with a trailer mounted knuckle boom loader (90.0\%), and delivered to the mill using a tractor-trailer (90.9\%). Regardless of the region, the high-production (upper third) businesses accounted for the majority of production. Over two-thirds of all production is harvested by the high-production (upper third) logging businesses. As markets for biomass increased, many loggers responded by adding a chipper to produce biomass; this was especially true among the high-production operations, where the majority in the Piedmont (60.7\%) and Coastal Plain (52.6\%) reported producing biomass.

Logging is a challenging business and many owners report a number of significant challenges to their business. However, this survey also indicates that the average production per crew and number of crews owned per business increased since the previous survey (2009). The average size of businesses appears to be increasing and much of the production capacity is concentrated in the high-production (upper third) businesses. The future health of the industry and the ability of the logging workforce to provide the wood needed by mills may depend on the success and viability of this group of higher production loggers. Despite many previous challenges, the logging workforce has continued to adapt with changing markets and other factors and will likely continue to do so in the future.

Acknowledgments: This project received financial and logistical support from the Virginia SHARP Logger Program, the Department of Forest Resources and Environmental Conservation (FREC) at Virginia Polytechnic Institute and State University, and the McIntire-Stennis Program of the National Institute of Food and Agriculture, U.S. Department of Agriculture. The Virginia Tech Open Access Subvention Fund (OASF) provided funding to publish in open access.

Author Contributions: Scott M. Barrett was involved in the original survey design, administered this survey, analyzed the data and wrote the manuscript. M. Chad Bolding and John F. Munsell were involved in the design of the original survey and reviewed and edited the manuscript.

Conflicts of Interest: The authors declare no conflict of interest.

\section{References}

1. Rephann, T.J. The Economic Impacts of Agriculture and Forest Industries in Virginia; Weldon Cooper Center for Public Service, University of Virginia: Charlottesville, VA, USA, 2013; pp. 31-37.

2. Virginia Department of Forestry. 2016 State of the Forrest. Available online: http://dof.virginia.gov/ infopubs/sof/SOF-2016pub.pdf (accessed on 12 September 2017).

3. Milauskas, S.J.; Wang, J. West Virginia logger characteristics. For. Prod. J. 2006, 56, 19.

4. Dirkswager, A.L.; Kilgore, M.A.; Becker, D.R.; Blinn, C.; Ek, A. Logging business practices and perspectives on harvesting forest residues for energy: A Minnesota case study. North. J. Appl. For. 2011, 28, 41-46.

5. Egan, A.; Taggart, D.; Annis, I. Effects of population pressures on wood procurement and logging opportunities in northern New England. North. J. Appl. For. 2007, 24, 85-90. 
6. Munsell, J.F.; Barrett, S.M.; Bolding, M.C. An exploratory study of biomass harvesting among logging firms in Virginia and North Carolina. For. Sci. 2011, 57, 427-434.

7. Allred, S.; Michler, C.; Mycroft, C. Midwest logging firm perspectives: Harvesting on increasingly parcelized forestlands. Int. J. For. Res. 2011, 2011. [CrossRef]

8. Moldenhauer, M.C.; Bolding, M.C. Parcelization of South Carolina's private forestland: Loggers' reactions to a growing threat. For. Prod. J. 2009, 59, 37.

9. Blinn, C.R.; O'Hara, T.J.; Chura, D.T.; Russell, M.B. Status of the Minnesota Logging Sector in 2011; Retrieved from the University of Minnesota Digital Conservancy; University of Minnesota: Saint Paul, MN, USA, 2014.

10. Baker, S.A.; Greene, W.D. Changes in Georgia's logging workforce, 1987-2007. South. J. Appl. For. 2008, 32, 60-68.

11. Bolding, M.C.; Barrett, S.M.; Munsell, J.F.; Groover, M.C. Characteristics of Virginia's logging businesses in a changing timber market. For. Prod. J. 2010, 60, 86-93. [CrossRef]

12. Virginia SHARP Logger Program. 2017. Available online: http://sharplogger.vt.edu/ (accessed on 26 October 2017).

13. Dangle, C.; Vinson, J.A.; Barrett, S.M. Regional Forest Harvest Characteristics across Virginia. Virginia Cooperative Extension Publication Number ANR-264NP. 2017. Available online: http:/ /www.pubs.ext.vt. edu/ANR/ANR-264/ANR-264.html (accessed on 11 July 2017).

14. Dillman, D.A. Mail and Internet Surveys: The Tailored Design Method; John Wiley \& Sons: New York, NY, USA, $2000 ;$ p. 480.

15. JMP, Version 13.0.0. Available online: https://www.jmp.com/en_us/home.html (accessed on 27 November 2017).

16. Cooper, J.; Becker, C. Virginia's Timber Industry-An Assessment of Timber Product Output and Use, 2007; Resour. Bull. SRS-155; Department of Agriculture Forest Service, Southern Research Station: Asheville, NC, USA, 2009; 33p.

17. Barrett, S.M.; Bolding, M.C.; Aust, W.M.; Munsell, J.F. Characteristics of logging businesses that harvest biomass for energy production. For. Prod. J. 2014, 64, 265-272. [CrossRef]

18. Cristan, R.; Aust, W.M.; Bolding, M.C.; Barrett, S.M.; Munsell, J.F.; Schilling, E. Effectiveness of forestry best management practices in the United States: Literature review. For. Ecol. Manag. 2016, 360, 133-151. [CrossRef]

(C) 2017 by the authors. Licensee MDPI, Basel, Switzerland. This article is an open access article distributed under the terms and conditions of the Creative Commons Attribution (CC BY) license (http://creativecommons.org/licenses/by/4.0/). 